\title{
New Criteria for Extrauterine Growth Restriction in Very Low-birth-weight Preterm Children and Neuropsychological Development at the Beginning of Primary School.
}

Gonzalo Solís ( $\square$ solisgonzalo@uniovi.es)

Hospital Universitario Central de Asturias https://orcid.org/0000-0003-0363-831X

Cristina Fernández-Baizán

Universidad de Oviedo Facultad de Psicologíao

Leticia Álcantara

Hospital Universitario Central de Asturias

Lara González-García

Hospital Universitario Central de Asturias

Enrique García-López

Hospital Universitario Central de Asturias

Jorge Luis Arias

Universidad de Oviedo, Facultad de Psicología

Marta Méndez

Universidad de Oviedo, Facultad de Psicología

\section{Research Article}

Keywords: Newborn, Prematurity, Growth, Neuropsychological test

Posted Date: March 17th, 2021

DOI: https://doi.org/10.21203/rs.3.rs-303860/v1

License: (c) (1) This work is licensed under a Creative Commons Attribution 4.0 International License.

Read Full License 


\section{Abstract}

Controversy between short-term neonatal growth of very low birth-weight preterm (VLBW) and neurodevelopment may be affected by new criteria of intra- and extrauterine growth restriction (IUGR and EUGR). Objective: To determine if IUGR and IUGR classic and new criteria are related to the neuropsychological development in VLBW. Patients and methods: 87 VLBW were studied at 5-7 years. Neuropsychological assessment included RIST test and NEPSY-II tests. Results of these tests were related to IUGR and EUGR classification using Fenton and INTERGROWTH-21 (IGW-21) graphs and standards. Results: Weight IUGR by Fenton and IGW-21 was 37.9 and 39.1\% (Kappa 0.879). Classic (static) EUGR was $89.7 \%$ and $75.9 \%$, respectively (Kappa 0.532). "True" EUGR was $52.9 \%$ and $36.8 \%$ (Kappa 0.683). Result of the RIST index was correlated with Fenton's z-score weight (0.034), length (< $0.001)$ and head circumference $(\mathrm{HC})(<0.001)$ at birth; with IGW-21's length $(0.002)$ at birth; with Fenton's weight (0.004) and length (0.003) at neonatal discharge; and with IGW-21's weight (0.004) and length $(0.003)$ at neonatal discharge. We found statistically significant differences in IQ when comparing cases with and without IUGR of weight, length and HC by Fenton; and length and HC by IGW-21; also we found differences in static EURG for length and HC for Fenton and IGW-21. In NEPSY-II subtasks we found some relationship in inhibitory control and visuospatial abilities. Conclusion: IUGR and EUGR classic and new concepts show different classification percentages of VLBW. This should be considered when assessing relationships with risk of alterations in neuropsychological tests at school initiation, due to the different results found depending on the classification criteria chosen.

\section{Background}

Brain development of newborn with very low birth weight (VLBW) depends largely on correct nutritional intake during immediate postnatal period. Nutrition and, therefore, body and brain growth in first weeks of life may be of great importance for neuropsychological development of these children (1).

Postnatal growth rate of VLBW and its relationship with neuropsychological development has been studied by many authors with different conclusions (2-9). Results variability are given by different growth parameters analysed, different neurodevelopmental tests used, and different ages studied. Of course, neurodevelopment is influenced by many other factors, pre- and postnatal, organic and social, that can confuse or modify this relationship (10-12).

When we analyze growth of premature infants in first weeks of life, two important questions arise: what ideal growth of these infants is? and what measure is the most opportune to verify it? (13-15).

American Academy of Pediatrics recommended since 1977 use fetal growth as ideal of postnatal growth in preterm infants (16). For this reason, most hospitals used reference curves based on cross-sectional measurements of weights of neonates at birth with different gestational ages (GA). In last 20 years, Olsen and Fenton's curves (17-19), with their progressive modifications, were basics in calculations and classifications of preterm infants, especially in developed countries. 
With these curves neonates were classified in percentiles or z-scores, in order to label neonates as small (IUGR), normal or large for their GA, in weight, length and cranial perimeter. But, in addition, they were used to label their growth from birth, during their neonatal stay, until 28 days, 36 weeks of GA or discharge, in order to assess so-called extrauterine growth restriction (EUGR).

However, in recent years, several changes in these concepts have been postulated. It is advocated not to use curves created with data from cross-sections at birth, but rather ones that define how a healthy premature baby should grow, without prenatal or postnatal complications throughout their first months of life $(15,20)$. This reasoning has changed 1997 AAP's paradigm to a new approach based on standards such as those of INTERGROWTH-21st Project (IGW-21), which publishes data on the growth of preterm infants from birth to week 64 of postmenstrual age $(21,22)$, then coupling to WHO curves (WHO Child Growth Standards (23)).

Articles have been published comparing both strategies, recalculating percentages of IUGR preterm infants (weight below 10th percentile at birth) and static EUGR (weight below 10th percentile at discharge, or at 36 weeks of corrected GA), differing according to graphs / standards used (24).

Another change that arises on this publications is whether we should call EUGR to all neonates who are below $10^{\text {th }}$ percentile at discharge or at 36 weeks of corrected GA, or only those who born above this percentile (non-IUGR) and are below it at discharge, what some authors call true EUGR (25). To end this discussion, other authors prefer to use dynamic concept of loss of 1 or 2 standard deviation (SD) in the zscore from birth to discharge, to speak of EUGR, what we could call dynamic EUGR.

In any case, debate remains open and discussion on the classification of premature infants, with static or dynamic criteria, creates new fronts in the effect of growth on the neuropsychological development of these children (2).

For all the above, we believe it is of interest to analyse neuropsychological functions at 5-7 years, (beginning of primary education) of a cohort of children under $1500 \mathrm{~g}$ at birth, relating their results with the somatometric and neonatal growth criteria used and modified in last years in literature.

\section{Patients And Methods}

An observational study was conducted, including 87 VLBW (less than $1500 \mathrm{~g}$ ) who were born in our Neonatology Service between 1/1/2009 and 1/1/2012.

In this period, 181 initial cases were born in our hospital, of which 34 died before discharge and 147 survivors were invited to participate in this study, responding affirmatively 87 cases (51 men and 36 women). All of them went to hospital for a clinical assessment and to carry out a neuropsychological study between February 2016 and May 2017. Comparing studied cases (87) and those that were not studied (60 lost cases), we did not find statistically significant differences neither in neonatal variables, nor in neurological evolution at medium-long term (Table 1). 
In 87 studied cases, protocol was completed with somatometry at birth, somatometry at discharge from neonatal admission, and at 2 years of chronological age corrected for GA. Birth and discharge data were analysed with Fenton and IGW-21 graphs and standards, and 2 years data with WHO graphs.

We define IUGR as cases born below 10th percentile for GA. We defined static (or cross-sectional) EUGR as cases that were below 10th percentile for GA at neonatal discharge. We define as true EUGR the cases that, born above 10th percentile (not IUGR), were discharged below 10th percentile for their GA. And we define dynamic (or longitudinal) EUGR cases that lost more than 1 or more than 2 SD from birth to discharge, regardless of their initial or final percentiles.

During the study visit, a neuropsychological evaluation was performed by psychologists, including an estimation of IQ, inhibitory control, verbal and visuospatial memory and visuospatial abilities, using RIST test and NEPSY-II battery.

RIST test (Reynols Intellectual Screening Test) is a screening test that provides a measure of an estimated IQ through two tasks, Riddles, a verbal task, and Categories, a non-verbal task. Its reliability coefficient varies between 0.89 and 0.91 depending on the age of child (5-7 years) and if it is the verbal or non-verbal subtest (26). For this study, the IQ values (mean 100, SD 15) are reported.

From NEPSY-II battery (27), the following subtasks were employed: Inhibition, as measure of inhibitory control; Memory for names subtask, which measures child's verbal memory capacity; Memory for designs subtask, that assess the ability to retain visual and spatial information; and Route finding, which measures visuospatial abilities, specifically, knowledge of visuospatial relationships and directionality. For this study, scalar scores from all these test are reported.

Usual tests were carried out in the statistical analysis, initially determining the normality of the variables with the Kolmogorov test. Variables with normal distribution were compared with Student's $t$ test. The variables whose distribution was not normal, and those variables score type, were compared using nonparametric statistics test (Mann Whitney $\mathrm{U}$ test). Comparisons of percentages were made with the Chisquare test (using Fisher's exact test if expected were less than 5). To establish correlations between zscores, Spearman Rho test was used. Finally, Kappa concordance test was used to compare Fenton and IWG-21 classifications.

Study was approved by the Research Ethics Committee of the Principality of Asturias.

\section{Results}

\section{1.- Description of the growth of 87 cases studied}

Somatometric data at birth, at discharge from neonatal admission and at 2 years of age can be seen in Table 2, while in Table 3 we can read the classifications at birth, at neonatal discharge and at 2 years according Fenton, IGW-21 and WHO graphs and standars. 
Percentage of low weight for their GA (less than 10th percentile or IUGR) for Fenton and IGW-21 were 37.9 and $39.1 \%$, respectively (Kappa 0.879). Percentage of cases weighing less than 10 th percentile at neonatal discharge (static or cross-sectional EUGR) were $89.7 \%$ for Fenton and 75.9\% for IGW-21 (Kappa 0.532). Percentage of cases that being born with weight above 10th percentile for Fenton and IGW-21, at discharge were below this percentile (true EUGR) were 85 and $60.4 \%$, corresponding to $52.8 \%$ ( 46 cases) and $36.8 \%$ (32 cases) of total, respectively for both Fenton and IGW-21 (Kappa 0.683). All true IGW-21 weight EUGRs were recognized by Fenton as true EUGRs, but $30 \%$ of Fenton's true weight EUGRs (14 cases) escape IGW-21 as true EUGRs.

\section{2.- Description of results of neuropsychological tests}

In Tables 4 and 5 are shown the global neuropsychological results carried out in 87 studied cases.

The RIST test, performed in 86 cases, was scored as high in 9 (10.3\%), as medium in $44(50.6 \%)$, as a deviation below mean in $23(26.4 \%)$ and as two deviations below mean in 10 cases $(11.5 \%)$. In the other tests, a level below or well below that expected was obtained in 11 cases (12.6\%) for the Inhibition task, in 8 cases $(9.2 \%)$ for Memory for names, in 27 cases (31\%) for Route finding test and in no case for Memory for designs.

Comparing scalar scores or IQ scores of different tests between cases with and without clinical neurological alterations diagnosed during evolution, we found statistically significant differences in Inhibition and in Route finding (Table 6).

\section{3.- Relationship between growth and neurological clinical evolution and neuropsychological tests}

There are not significant associations between growth disturbance and to have a clinical neurological alteration, except for the loss of 2 SD in length between birth and neonatal discharge for Fenton (Table 7).

We found statistically significant correlations between RIST index and z-score for Fenton at birth (weight, length and HC), for IGW-21 at birth (length); for Fenton at discharge (weight and length); for IGW-21 at discharge (weight and length). We did not find any statistically significant correlation between RIST and $z$-scores at 2 years, nor between any of other tests analysed with any of measures studied (Table 8).

Comparing scalar or IQ values of different tests between established cut-off points we found some statistically significant differences that can be read in detail in Table IX. IQ scores from RIST index showed statistically significant differences for the IUGR of weight, length and HC; for static EUGR of length and $\mathrm{HC}$; and for $\mathrm{HC}$ less than 2SD at 2 years.

We did not find any statistically significant difference for Memory for names nor for Memory for designs. For Inhibition task, we found statistically significant differences for IUGR for Fenton and IGW-21, for the 
classification of true EUGR of weight for IGW-21 (-1SD between birth and discharge) and for height and $\mathrm{HC}$ at 2 years. In Route finding task we found differences for static HC EUGR <-2DS for Fenton and IGW21, and for dynamic HC IGW-21 EUGR at -2DS. All differences found were in favour of normal data (not IUGR or not EUGR), except for inhibition task and true EUGR, in which we found better performance in those cases with true EUGR. As seen in Table 9, clinical importance of statistically significant differences found is highly variable.

\section{Discussion}

VLBW may be due to prematurity and / or IUGR of different etiologies. Later, growth of these neonates can be influenced by multiple genetic, epigenetic, neonatal (respiratory, cardiac, infectious, nutritional, etc.) and post-neonatal (nutrition, morbidity, culture, etc.) factors. On the other hand, neurodevelopment of these children is also influenced by different factors, coinciding some of them with the above mentioned and being some of them related to other matters (parental intelligence, socio-family level, education, etc.). In published observational studies, it has been analyzed whether growth is related to neurodevelopment in short, medium and long term, although the conclusions are not uniform and debate remains open (2-9).

Beyond neurological alterations diagnosed clinically in follow-up (motor, sensory, cognitive, behavioral, ...), VLBW may present neuropsychological alterations at school age, only detectable by specific tests for this purpose, such RIST test and NEPSY-II battery at 5-7 years $(11,28)$. For this reason, our study aimed to know relationship between result of these tests and initial growth of VLBW, comparing different definitions of neonatal growth, without entering into the influence of other neonatal factors that are already present in previous publications (11).

\section{Growth.}

One of the major problems that arises when assessing relationship between neonatal growth and subsequent neurodevelopment is which growth parameters and somatometry to use. Classically, Fenton 's 10th percentile was cut-off at birth and neonatal discharge for classifying children as IUGR and EUGR, but this classification is now obsolete. First, IGW-21 standards seem much more interesting as basic data, given the way they are obtained (longitudinal with healthy preterm infants), to classify children (21), although it is still not clear whether we should call all those under 10th percentile at discharge or if we should only use this term for those who, born above 10th percentile, go from discharge below it. Other authors go further, proposing that EUGR concept should be based on the reduction of standard deviations, rather than static percentiles, adding a dynamic and critical look to this discussion. This is how the concept of static (or transverse) EUGR and dynamic (or longitudinal) EUGR arose, being this latter the currently preferred $(2,4,16,29,30)$.

Our small series aimed to evaluate these aspects, analysing static somatometric data (weight, length and $\mathrm{HC}$ at birth and discharge), but also some dynamic ones (true EUGR and changes less or greater than -1 
and -2 SD between birth and discharge), both for Fenton and IGW-21. Our results support that the percentage of VLBW classified as IUGR and EUGR vary greatly depending on criteria used.

Thus, IGW-21 is slightly less selective at birth in IUGR classification (most cases than Fenton) but, at the same time, stricter at discharge in the static EUGR classification for weight (less cases less than Fenton), which makes some true Fenton-tagged EUGRs slip away (30.4\% in our series), while Fenton doesn't miss any of the IGW-21-tagged ones. The same does not happen with length and with $\mathrm{CP}$, which do not present a uniform trend, contrary to what appears in other series (31).

\section{Neuropsychological test}

In our 87 VLBW, we found no differences in somatometry at birth and in their growth up to 2 years of age between children with and without neurological alteration clinically diagnosed at 5-7 years, but in neuropsychological tests performed at this age. With RIST index and NEPSY-II battery we have verified that, in addition to static somatometry at birth, certain parameters of neonatal growth and during the first 2 years of life influence the performance of these children at study age.

RIST is a screening test that provides us with a measure of estimated IQ, which, in our series, was correlated with z-score at birth (Fenton's weight, length and HC, and IGW-21's length) and at neonatal discharge (Fenton and IGW-21 weight and length), but not with z-score differences between birth and neonatal discharge, nor with the z-score at 2 years. In addition, IUGRs in weight, length and HC, and static EUGRs in length and HC show lower scores, statistically significant, compared to neonates who were not, with differences of 10-20 points between them. Same occurs with neonates who present HC score less than $2 \mathrm{SD}$ for WHO at 2 years. These results coincide partially with the previous literature, finding that some neonatal and early postnatal measures which indicated a lower growth status could be related with later and lower IQ achievements (2).

However, it is also worth mentioning major methodological differences of our study with some previous publications, such as the use of different definitions of EUGR, with Fenton and IGW-21 graphs and standars. Therefore, it seems that the use of these new approaches may be of interest, as a possible predictor of subsequent neuropsychological development.

Another issue to consider would be the different importance given to the IQ in these previous publications. As it has been said before, while previous articles are focused on IQ assessment as the only measurement of cognitive development, our aim was to consider a wider neuropsychological profile, and due to that, RIST test was included only as a screening measure of IQ. With these results, we must admit that RIST index is mathematically related with static somatometric values at birth and discharge, but not with dynamic ones. In any case, this relationship, as we discussed previously, can be influenced by many other prior or intermediate factors that surely play important roles. 
In NEPSY-II tests, we found some interesting relationships, although we did not find a clear pattern between growth and the different subtasks. It is striking, for example, that Memory for names and Memory for design tasks, related to verbal and visuospatial memory respectively, did not present any type of relationship (neither correlation nor statistically significant differences) with any growth parameter. This may be due to the fact that the memory scores reported in the present study are composite indexes of both short- and long-term memory, which are related but independent cognitive functions and their addition could decrease their ability to differentiate between growth statuses. Besides, it should be noticed that in Memory for designs, any of our participants scored below expected, and then, this can limit the discriminatory capacity of such task.

We also did not find correlations between scalar scores of other studied NEPSY-II subtasks (Inhibition and Route finding subtasks), although we were able to determine some statistically significant differences for some growth items, but without a clear pattern of behavior or clinical differences, important enough to be highlighted. These findings could point to the possibility that slower growth does not affect specific neuropsychological functions, but rather a more global pattern of cognitive development.

In summary, classification IUGR and EUGR (static, dynamic and true) with Fenton and IGW-21 show very varied percentages according to the criteria used in the classification. Besides, growth influence on neuropsychological tests does not seem robust, except for IQ measurement, which is clearly correlated with some static measures and which shows clinically important differences between some groups classified according to these measurements.

New IUGR and EUGR concepts should be evaluated in future studies in this field since, probably, they catalog neuropsychological risk groups differently and modify ideas that were maintained up to that moment. Reviewing growth importance in first weeks of life in later neurodevelopment is a topic of great interest to neonatologists, endocrinologists, neurologists, and psychologists.

\section{Abbreviations}

EUGR

extrauterine growth restriction

GA

gestational age

$\mathrm{HC}$

head circumference

IGW-21

Intergrowth-21st Project

IUGR

intrauterine growth restriction

RIST

Reynols Intellectual Screening Test 
VLBW

very low birth weight

$\mathrm{WHO}$

World Health Organization

\section{References}

1. Belfort MB, Ehrenkranz RA. Neurodevelopmental outcomes and nutritional strategies in very low birth weight infants. Sem Fetal Neon Med. 2017; 22: 42-48. DOI: 10.1016/j.siny.2016.09.001

2. Fenton TR, Cormack B, Goldberg D, Nasser R, Alshaikh B, Eliasziw M, Hay WW, Hoyos A, Anderson D, Bloomfield F, Griffin I, Embleton N, Rochow N, Taylor S, Senterre T, Schanler RJ, Elmrayed S, GrohWargo S, Adamkin D, Shah PS. "Extrauterine growth restriction" and "postnatal growth failure" are misnomers for preterm infants. J Perinatol. 2020; 40: 704-714. DOI: 10.1038/s41372-020-0658-5

3. Shah PS, Wong KY, Merko S, Bishara R, Dunn M, Asztalos E, Darling PB. Postnatal growth failure in preterm infants: ascertainment and relation to long-term outcome. J Perinat Med. 2006; 34: 484-9. DOI: 10.1515/JPM.2006.094

4. Zozaya C, Díaz C, Saenz de Pipaón M. How should we define postnatal growth restriction in preterm infants? Neonatology. 2018; 114: 177-80. DOI: 10.1159/000489388

5. Franz AR, Pohlandt F, Bode H, Mihatsch WA, Sander S, Kron M, et al. Intrauterine, early neonatal, and postdischarge growth and neurodevelopmental outcome at 5.4 years in extremely preterm infants after intensive neonatal nutritional support. Pediatrics. 2009; 123: e101-9. DOI: 10.1542/peds.20081352

6. Ehrenkranz RA, Dusick AM, Vohr BR, Wright LL, Wrage LA, Poole WK. Growth in the neonatal intensive care unit influences neurodevelopmental and growth outcomes of extremely low birth weight infants. Pediatrics. 2006; 117: 1253-61. DOI: 10.1542/peds.2005-1368

7. Ong KK, Kennedy K, Castañeda-Gutiérrez E, Forsyth S, Godfrey KM, Koletzko B, et al. Postnatal growth in preterm infants and later health outcomes: a systematic review. Acta Paediatr. 2015; 104: 974-86. DOI: $10.1111 /$ apa.13128

8. Belfort MB, Gillman MW, Buka SL, Casey PH, McCormick MC. Preterm infant linear growth and adiposity gain: trade-offs for later weight status and intelligence quotient. J Pediatr. 2013; 163 : 1564-9. DOI: 10.1016/j.jpeds.2013.06.032

9. Guellec I, Lapillonne A, Marret S, Picaud J-C, Mitanchez D, Charkaluk M-L, et al. Effect of intra- and extrauterine growth on long-term neurologic outcomes of very preterm infants. J Pediatr. 2016; 175: 93-99.e1. DOI: 10.1016/j.jpeds.2016.05.027

10. Lean RE, Paul RA, Smyser TA, Smyser CD, Rogers CE. Social Adversity and Cognitive, Language, and Motor Development of Very Preterm Children from 2 to 5 Years of Age. J Pediatr. 2018; 203: 177184.e1. DOI: 10.1016/j.jpeds.2018.07.110

11. Fernandez-Baizan C, Alcántara-Canabal L, Solis G, Mendez M. The association between perinatal and neonatal variables and neuropsychological development in very and extremely low-birth-weight 
preterm children at the beginning of primary school. Appl Neuropsychol Child. 2020. Ahead of print. doi: 10.1080/21622965.2019.1709464. DOI: 10.1080/21622965.2019.1709464

12. Twilhaar ES, Wade RM, de Kieviet JF, van Goudoever JB, van Elburg RM, Oosterlaan J. Cognitive Outcomes of Children Born Extremely or Very Preterm Since the 1990s and Associated Risk Factors: A Meta-analysis and Meta-regression. JAMA Pediatr. 2018; 172: 361-367.

DOI: 10.1001/jamapediatrics.2017.5323

13. Giuliani F, Ismail LC, Bertino E, Bhutta ZA, Ohuma EO, Rovelli I. Monitoring postnatal growth of preterm infants: Present and future. Am J Clin Nutr. 2016; 103: 635S-647S.

DOI: 10.3945/ajcn.114.106310

14. Pearson F, Johnson MJ. How should we chart the growth of very preterm babies? Arch Dis Child Fetal Neonatal Ed. 2019; 104: F120-F121. DOI: 10.1136/archdischild-2018-315223

15. Izquierdo Renau M, Aldecoa-Bilbao V, Balcells Esponera C, Del Rey Hurtado de Mendoza B, Iriondo Sanz M, Iglesias-Platas I. Applying Methods for Postnatal Growth Assessment in the Clinical Setting: Evaluation in a Longitudinal Cohort of Very Preterm Infants. Nutrients. 2019; 11: 2772. doi: 10.3390/nu11112772. DOI: 10.3390/nu11112772

16. American Academy of Pediatrics, Committee on Nutrition. Nutritional needs of low-birth-weight infants. Pediatrics. 1977; 60: 519-530.

17. Olsen IE, Groveman SA, LawsonML, Clark RH, Zemel BS. New intrauterine growth curves based on United States data. Pediatrics. 2010; 125: e214-e224. DOI: 10.1542/peds.2009-0913

18. Fenton TR. A new growth chart for preterm babies: Babson and Benda's chart updated with recent data and a new format. BMC Pediatr. 2003; 3: 13. DOI: 10.1186/1471-2431-3-13

19. Fenton TR, Kim JH. A systematic review and meta-analysis to revise the Fenton growth chart for preterm infants. BMC Pediatr. 2013; 13: 59. DOI: 10.1186/1471-2431-13-59

20. Ehrenkranz RA, Younes N, Lemons JA, Fanaroff AA, Donovan EF, Wright LL, Katsikiotis V, Tyson JE, OhW, Shankaran S, Bauer CR, Korones SB, Stoll BJ, Stevenson DK, Papile LA. Longitudinal growth of hospitalized very low birth weight infants. Pediatrics. 1999; 104: 280-289.

DOI: $10.1542 /$ peds. 104.2 .280

21. Villar J, Giuliani F, Barros F, Roggero P, Coronado Zarco IA,MAS R, Ochieng R, GianniML, Rao S, Lambert A, Ryumina I, Britto C, Chawla D, Cheikh Ismail L, Rehan Ali S, Hirst J, Singh Teji J, Abawi K, Asibey J, Agyeman-Duah J, McCormick K, Bertino E, Papageorghiou AT, Figueras-Aloy J, Bhutta Z, Kennedy S. Monitoring the Postnatal Growth of Preterm Infants: A Paradigm Change. Pediatrics. 2018; 141: e20172467. DOI: 10.1542/peds.2017-2467

22. Villar J, Giuliani F, Butta ZA, Bertino E, Ohuma EO, Ismail LC, Barros FC, Altman DG, Victora C, Noble JA, Gravett MG, Purwar M, Pang R, Lambert A, Papageorghiou AT, Ochieng R, Jaffer YA, Kennedy SH, International Fetal and Newborn Growth Consortium for the 21st Century (INTERGROWTH-21st). Postnatal growth standards for preterm infants: the Preterm Postnatal Follow-up Study of the INTERGROWTH-21st Project. Lancet Glob Health. 2015; 3: e681-e691. DOI: 10.1016/S2214109X(15)00163-1 
23. WHO Multicentre Growth Reference Study Group. WHO child growth standards based on length/height, weight and age. Acta Paediatr. 2006; Suppl 450: 76-85. DOI: 10.1111/j.16512227.2006.tb02378.x

24. Reddy KV, Sharma D, Vardhelli V, Bashir T, Deshbotla SK, Murki S. Comparison of Fenton 2013 growth curves and Intergrowth-21 growth standards to assess the incidence of intrauterine growth restriction and extrauterine growth restriction in preterm neonates $\leq 32$ weeks. J Matern Fetal Neonatal Med. 2019. DOI: 10.1080/14767058.2019.1670795 Epub ahead of print.

25. Figueras-Aloy J, Palet-Trujols C, Matas-Barceló I, Botet-Mussons F, Carbonell-Estrany X. Extrauterine growth restriction in very preterm infant: etiology, diagnosis, and 2-year follow-up. Eur J Pediatr. 2020; 179: 1469-1479. DOI: 10.1007/s00431-020-03628-1

26. Reynols CR, Kamphaus RW. RIAS (Reynols Intellectual Assessment Scales) and the RIST (Reynols Intellectual Screening Test). Professional Manual Lutz, Florida. Psychological Assessement Resources. 2003.

27. Korkman M, Kirk U, Kemp S. NEPSY-II. A developmental neuropsychological assessment. San Antonio. TX: The Psychological Corporation. 2007.

28. Fernandez-Baizan C, Alcantara-Canabal L, Solis G, Mendez M. Development of egocentric and allocentric spatial orientation abilities in children born preterm with very low birth weight. Early Hum Dev. 2020; 141: 104947. DOI: 10.1016/j.earlhumdev.2019.104947

29. Lee SM, Kim N, Namgung R, Park M, Park K, Jeon J. Prediction of Postnatal Growth Failure among Very Low Birth Weight Infants. Sci Rep. 2018; 8: 3729. DOI: 10.1038/s41598-018-21647-9

30. Peila C, Spada E, Giuliani F, Maiocco G, Raia M, Cresi F, Bertino E, Coscia A. Extrauterine Growth Restriction: Definitions and Predictability of Outcomes in a Cohort of Very Low Birth Weight Infants or Preterm Neonates. Nutrients. 2020; 12: 1224. DOI: 10.3390/nu12051224

31. Kim YJ, Shin SH, Cho H, Shin SH, Kim SH, Song IG, Kim EK, Kim HS. Extrauterine growth restriction in extremely preterm infants based on the Intergrowth-21st Project Preterm Postnatal Follow-up Study growth charts and the Fenton growth charts. Eur J Pediatr. 2020. DOI: 10.1007/s00431-020-03796-0 Epub ahead of print.

\section{Tables}


Table 1

Comparison between studied cases and survivors not studied (lost) for the perinatal and neonatal variables.

\begin{tabular}{|c|c|c|c|}
\hline & $\begin{array}{l}\text { Studied } \\
\text { cases }(\mathrm{n}= \\
87)\end{array}$ & $\begin{array}{l}\text { Survivors not studied } \\
\text { (lost) }(n=60)\end{array}$ & $\begin{array}{l}\text { Statistical } \\
\text { significance }\end{array}$ \\
\hline Weight (g): median (IQR) & $1220(430)$ & $1163(413)$ & $0,682^{*}$ \\
\hline Gestational age (weeks) mean (Cl 95\%) & $\begin{array}{l}29,6(29,0- \\
30,2)\end{array}$ & $29,8(29,0-30,6)$ & 0,774 ** \\
\hline Sex: male/female (n) & $51 / 36$ & $31 / 29$ & $0,404 * \star *$ \\
\hline Multiple birth (n) & 30 & 15 & 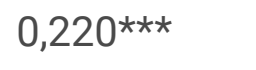 \\
\hline Type of delivery: Vaginal /Cesarean (n) & $27 / 60$ & $23 / 37$ & $0,359 * \star \star$ \\
\hline $\begin{array}{l}\text { Apgar test } 1 \text { minute }(\mathrm{n}) \\
-0-3 / 4-6 />6\end{array}$ & $9 / 16 / 62$ & $4 / 10 / 46$ & $0,689 * \star \star$ \\
\hline $\begin{array}{l}\text { Apgar test } 5 \text { minutes }(n) \\
-0-3 / 4-6 />6\end{array}$ & $1 / 5 / 81$ & $2 / 0 / 58$ & $0,115^{\star \star \star}$ \\
\hline $\begin{array}{l}\text { Neonatal resuscitation (n) } \\
\text { - Oxygen } \\
\text { - Ambu with mask } \\
\text { - CPAP nasal } \\
\text { - Intubatión } \\
\text { - Heart massage and/or Drugs }\end{array}$ & $\begin{array}{l}74 \\
57 \\
26 \\
35 \\
7\end{array}$ & $\begin{array}{l}49 \\
32 \\
18 \\
18 \\
2\end{array}$ & $\begin{array}{l}0,585^{\star \star \star} \\
0,137^{\star \star \star} \\
0,737^{\star \star \star} \\
0,204^{\star \star \star} \\
0,188^{\star \star \star}\end{array}$ \\
\hline CRIB index 12 hours (median (IQR)) & $1(3)$ & $1(2)$ & $0,434^{*}$ \\
\hline $\begin{array}{l}\text { Respiratory support: } \\
\text { - Oxygen } \\
\text { - Non-invasive ventilation (IMVn) } \\
\text { - Conventional ventilación } \\
\text { - High frecuency ventilation }\end{array}$ & $\begin{array}{l}78 \\
46 \\
47 \\
2\end{array}$ & $\begin{array}{l}51 \\
33 \\
37 \\
2\end{array}$ & $\begin{array}{l}0,397 * \star \star \\
0,799 * \star \star \\
0,357 * \star \star \\
0,705^{\star * \star}\end{array}$ \\
\hline Surfactant & 45 & 33 & $0,695^{\star \star \star}$ \\
\hline $\begin{array}{l}\text { Diagnoses: } \\
\text { - Hyaline membrane disease } \\
\text { - Pneumothorax } \\
\text { - Patent ductus arteriosus } \\
\text { - Necrotizing enterocolitis } \\
\text { - Early sepsis } \\
\text { - Transfusible anemia } \\
\text { - Late sepsis }\end{array}$ & $\begin{array}{l}43 \\
2 \\
21 \\
4 \\
1 \\
35 \\
23\end{array}$ & $\begin{array}{l}31 \\
4 \\
16 \\
1 \\
2 \\
23 \\
18\end{array}$ & $\begin{array}{l}0,789^{\star \star \star} \\
0,188^{\star \star \star} \\
0,728^{\star \star \star} \\
0,335^{\star \star \star} \\
0,357^{\star \star \star} \\
0,678^{\star \star \star} \\
0,636^{\star \star \star}\end{array}$ \\
\hline $\begin{array}{l}\text { Intracranial hemorrhage } \\
\text { - No } \\
\text { - I or II } \\
\text { - III or IV }\end{array}$ & $\begin{array}{l}64 \\
21 \\
2\end{array}$ & $\begin{array}{l}41 \\
15 \\
4\end{array}$ & $0,562^{\star \star \star}$ \\
\hline
\end{tabular}




\begin{tabular}{|c|c|c|c|}
\hline & $\begin{array}{l}\text { Studied } \\
\text { cases }(n= \\
87)\end{array}$ & $\begin{array}{l}\text { Survivors not studied } \\
\text { (lost) }(n=60)\end{array}$ & $\begin{array}{l}\text { Statistical } \\
\text { significance }\end{array}$ \\
\hline Periventricular leukomalacia & 9 & 6 & $0,774 * \star \star$ \\
\hline $\begin{array}{l}\text { Retinopathy of prematurity } \\
\text { - No } \\
\text { - I } \\
\text { - II or III } \\
\text { - Fundus not performed }\end{array}$ & $\begin{array}{l}55 \\
13 \\
15 \\
4\end{array}$ & $\begin{array}{l}40 \\
8 \\
9 \\
3\end{array}$ & $0,985^{\star \star \star}$ \\
\hline $\begin{array}{l}\text { Neurological evolution: } \\
\text { - Neurological disorders of any kind } \\
\text { - Major neurological disorders } \\
\text { - Congenital alterations not related } \\
\text { - Cerebral palsy } \\
\text { - Severe developmental disorders } \\
\text { - Language disorders } \\
\text { - Behavioral disorders and / or attention } \\
\text { deficit hyperactivity disorder }\end{array}$ & $\begin{array}{l}19 \\
7 \\
2 \\
5 \\
3 \\
12 \\
3\end{array}$ & $\begin{array}{l}14 \\
8 \\
2 \\
5 \\
2 \\
4 \\
2\end{array}$ & 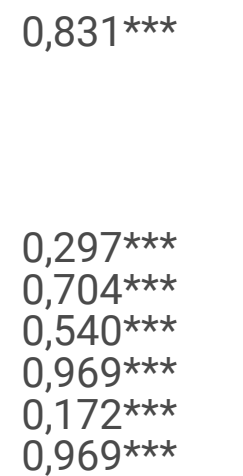 \\
\hline
\end{tabular}

Table 2

Somatometry at birth, neonatal discharge and at 2 years of the 87 neonates followed.

\begin{tabular}{|llll|}
\hline & Weight $\mathbf{( g )}$ & Length $(\mathbf{c m})$ & Head circunference $(\mathbf{c m})$ \\
\hline $\begin{array}{l}\text { Birth } \\
\text { - Mean (CI 95\%) }\end{array}$ & $1153(1101-1204)$ & $37,8(37,1-38,5)$ & $26,2(25,7-26,7)$ \\
- Median (IQR) & $1220(430)$ & $38,0(5)$ & $27,0(4)$ \\
\hline $\begin{array}{l}\text { Neonatal discharge } \\
\text { - Mean (CI 95\%) }\end{array}$ & $2325(2277-2372)$ & $45,4(45,0-45,8)$ & $33,2(32,9-33,5)$ \\
- Median (IQR) & & $45,0(2,5)$ & $33,0(1,5)$ \\
\hline 2 years & $11403(11030-11775)$ & $86,0(84,9-87,1)$ & $48,4(48,0-49,8)$ \\
- Mean (CI 95\%) & $11425(2100)$ & $86,0(6,5)$ & $48,5(2,0)$ \\
- Median (IQR) & & & \\
\hline
\end{tabular}


Table 3

Classification at birth, neonatal discharge and at 2 years, by Fenton, Intergrow-21 and WHO (n,\%)

\begin{tabular}{|c|c|c|c|c|}
\hline & & Weight & Length & $\begin{array}{l}\text { Head } \\
\text { circumference }\end{array}$ \\
\hline Birth & $\begin{array}{l}\text { IUGR } \\
\text { - Fenton less than P10 } \\
\text { - IGW-21 less tan P10 } \\
\text { Kappa concordance }\end{array}$ & $\begin{array}{l}33 \\
(37.9 \%) \\
34 \\
(39.1 \%) \\
0.879\end{array}$ & $\begin{array}{l}23 \\
(26.4 \%) \\
28 \\
(32.2 \%) \\
0.807\end{array}$ & $\begin{array}{l}29(33.3 \%) \\
34(39.1 \%) \\
0.826\end{array}$ \\
\hline \multirow[t]{3}{*}{$\begin{array}{l}\text { Neonatal } \\
\text { discharge }\end{array}$} & $\begin{array}{l}\text { Static EUGR (cross- } \\
\text { sectional) } \\
\text { - Fenton less than P10 } \\
\text { - IGW-21 less than P10 } \\
\text { Kappa concordance } \\
\text { - Fenton less than - 2SD } \\
\text { - IGW-21 less than - 2SD } \\
\text { Kappa concordance }\end{array}$ & $\begin{array}{l}78 \\
(89.7 \%) \\
66 \\
(75.9 \%) \\
0.532 \\
50 \\
(57.5 \%) \\
41 \\
(47.1 \%) \\
0.795\end{array}$ & $\begin{array}{l}68 \\
(78.2 \%) \\
63 \\
(72.4 \%) \\
0.785 \\
41 \\
(47.1 \%) \\
42 \\
(48.3 \%) \\
0.839\end{array}$ & $\begin{array}{l}25(28.7 \%) \\
28(32.2 \%) \\
0.810 \\
11(12.6 \%) \\
15(17.2 \%) \\
0.820\end{array}$ \\
\hline & $\begin{array}{l}\text { True EUGR } \\
\text { - For Fenton } \\
\text { - For IGW-21 } \\
\text { Kappa concordance }\end{array}$ & $\begin{array}{l}46 \\
(52.8 \%) \\
32 \\
(36.8 \%) \\
0.683\end{array}$ & $\begin{array}{l}45 \\
(51.7 \%) \\
38 \\
(43.6 \%) \\
0.748\end{array}$ & $\begin{array}{l}9(10.3 \%) \\
10(11.5 \%) \\
0.705\end{array}$ \\
\hline & $\begin{array}{l}\text { Dinamic EUGR (logitudinal) } \\
\text { - More than - } 1 \text { SD Fenton } \\
\text { - More than - } 1 \text { SD IGW-21 } \\
\text { Kappa concordance } \\
\text { - More than - } 2 \text { SD Fenton } \\
\text { - More than - 2 DS IGW-21 } \\
\text { Kappa concordance }\end{array}$ & $\begin{array}{l}54 \\
(62.1 \%) \\
41 \\
(47.1 \%) \\
0.705 \\
23 \\
(26.4 \%) \\
19 \\
(21.8 \%) \\
0.875\end{array}$ & $\begin{array}{l}56 \\
(64.4 \%) \\
45 \\
(48.3 \%) \\
0.605 \\
26 \\
(29.9 \%) \\
26 \\
(29.9 \%) \\
0.890\end{array}$ & $\begin{array}{l}17(19.5 \%) \\
17(19.5 \%) \\
0,781 \\
8(9.2 \%) \\
8(9.2 \%) \\
0.862\end{array}$ \\
\hline 2 years & - OMS les than - 2DS & $\begin{array}{l}12 \\
(15.2 \%)\end{array}$ & $7(8.9 \%)$ & $4(5.1 \%)$ \\
\hline
\end{tabular}


Table 4

IQ for RIST and scalar scores for Inhibition, Memory for names, Memory for designs, and Route finding assessed in

87 studied cases at $5-7$ years divided in percentiles

\begin{tabular}{|llllll|}
\hline & P5 & P25 & P50 & P75 & P95 \\
\hline RIST & 58,8 & 78,7 & 91 & 101 & 117 \\
\hline Inhibition & 3 & 7 & 9 & 11 & 13,6 \\
\hline Memory for names & 5 & 8 & 10 & 12 & 15 \\
\hline Memory for designs & 6 & 8 & 10 & 12 & 13,6 \\
\hline Route finding & 0 & 1 & 2 & 4 & 8,6 \\
\hline
\end{tabular}

Table 5

Results of neuropsychological assessment grouped into categories (case numbers and percentages).

\begin{tabular}{|lllll|}
\hline & Inhibition & Memory for names & Memory for designs & Route finding \\
\hline Far below expected level & $5(5,7 \%)$ & $2(2,3 \%)$ & $0(0 \%)$ & $4(4,6 \%)$ \\
\hline Below expected level & $6(6,9 \%)$ & $6(6,9 \%)$ & $0(0 \%)$ & $23(26,4 \%)$ \\
\hline Borderline & $14(16,1 \%)$ & $8(9,2 \%)$ & $13(14.9 \%)$ & $27(31 \%)$ \\
\hline Expected level & $51(58,6 \%)$ & $51(58,6 \%)$ & $67(77 \%)$ & $27(31 \%)$ \\
\hline Above expected level & $11(12,6 \%)$ & $20(23 \%)$ & $7(8 \%)$ & $6(6,9 \%)$ \\
\hline
\end{tabular}




\section{Table 6}

Comparison of scalar scores for Inhibition, Memory for names, Memory for designs and Route finding, and of IQ for RIST, between cases with and without diagnosed clinical neurological disorders.

\begin{tabular}{|llll|}
\hline & $\begin{array}{l}\text { Diagnosed clinical } \\
\text { neurological disorders } \\
(\mathbf{n}=19)\end{array}$ & $\begin{array}{l}\text { Not diagnosed clinical } \\
\text { neurological disorders } \\
(\mathbf{N}=68)\end{array}$ & $\begin{array}{l}\text { Est sig } \\
*(\mathbf{p})\end{array}$ \\
\hline RIST (median (IQR)) & $89(42)$ & $91(18)$ & 0,426 \\
\hline $\begin{array}{l}\text { Inhibition (median } \\
(\text { IQR)) }\end{array}$ & $7(5)$ & $10(4)$ & 0,002 \\
\hline $\begin{array}{l}\text { Memory for names } \\
\text { (median (IQR)) }\end{array}$ & $9(7)$ & $10(4)$ & 0,492 \\
\hline $\begin{array}{l}\text { Memory for designs } \\
\text { (median (IQR)) }\end{array}$ & $10(3)$ & $10(4)$ & 0,630 \\
\hline $\begin{array}{l}\text { Route finding (median } \\
(\text { IQR)) }\end{array}$ & $1(1)$ & $3(4)$ & 0,010 \\
\hline
\end{tabular}


Table 7

Comparison of groups with and without evolutionary neurological alteration in relation to various somatometric parameters.

\begin{tabular}{|c|c|c|c|c|}
\hline & & $\begin{array}{l}\text { Diagnosed clinical } \\
\text { neurological disorders } \\
(n=19)\end{array}$ & $\begin{array}{l}\text { Not diagnosed clinical } \\
\text { neurological disorders } \\
(\mathrm{N}=68)\end{array}$ & $\begin{array}{l}\text { Est } \\
\text { sig ( } p)\end{array}$ \\
\hline IUGR & $\begin{array}{l}\text { - Weight } \\
\text { Fenton < P10 } \\
\text { - Weight IGW- } \\
21<\text { P10 } \\
\text { - Length } \\
\text { Fenton < P10 } \\
\text { - Length IGW- } \\
21<\text { P10 } \\
\text { - HC Fenton } \\
<\text { P10 } \\
\text { - HC IGW-21 } \\
<\text { P10 }\end{array}$ & $\begin{array}{l}7(36,8 \%) \\
7(36,8 \%) \\
5(26,3 \%) \\
7(36,8 \%) \\
6(31,6 \%) \\
7(36,8 \%)\end{array}$ & $\begin{array}{l}26(38,2 \%) \\
27(39,7 \%) \\
18(26,5 \%) \\
21(30,9 \%) \\
23(33,8 \%) \\
27(39,7 \%)\end{array}$ & $\begin{array}{l}0,912 \\
0,821 \\
0,989 \\
0,623 \\
0,854 \\
0,821\end{array}$ \\
\hline $\begin{array}{l}\text { Static EUGR } \\
\text { (cross-sectional) }\end{array}$ & $\begin{array}{l}\text { - Weight } \\
\text { Fenton < P10 } \\
\text { - Weight } \\
\text { Fenton } \\
<-2 D S \\
\text { - Weight IGW- } \\
21<\text { P10 } \\
\text { - Weight IGW- } \\
21<-2 D S \\
\text { - Length } \\
\text { Fenton < P10 } \\
\text { - Length } \\
\text { Fenton } \\
\text { <-2DS } \\
\text { - Length IGW- } \\
21<\text { P10 } \\
\text { - Length IGW- } \\
\text { 21 <-2DS } \\
\text { - HC Fenton } \\
<\text { P10 } \\
\text { - HC Fenton } \\
<-2 D S \\
\text { - HC IGW-21 } \\
<\text { P10 } \\
\text { - HC IGW-21 } \\
<-2 D S\end{array}$ & $\begin{array}{l}17(89,2 \%) \\
13(68,4 \%) \\
14(73,7 \%) \\
9(47,4 \%) \\
17(89,5 \%) \\
9(47,4 \%) \\
16(84,2 \%) \\
11(57,9 \%) \\
6(31,6 \%) \\
3(15,8 \%) \\
6(31,6 \%) \\
5(26,3 \%)\end{array}$ & $\begin{array}{l}61(89,7 \%) \\
37(54,4 \%) \\
52(76,5 \%) \\
32(47,1 \%) \\
51(75 \%) \\
32(47,1 \%) \\
47(69,1 \%) \\
31(45,6 \%) \\
19(27,9 \%) \\
8(11,8 \%) \\
22(32,4 \%) \\
10(14,7 \%)\end{array}$ & $\begin{array}{l}0,977 \\
0,275 \\
0,802 \\
0,981 \\
0,177 \\
0,981 \\
0,193 \\
0,343 \\
0,757 \\
0,641 \\
0,949 \\
0,236\end{array}$ \\
\hline
\end{tabular}




\begin{tabular}{|c|c|c|c|c|}
\hline & & $\begin{array}{l}\text { Diagnosed clinical } \\
\text { neurological disorders } \\
(n=19)\end{array}$ & $\begin{array}{l}\text { Not diagnosed clinical } \\
\text { neurological disorders } \\
(\mathrm{N}=68)\end{array}$ & $\begin{array}{l}\text { Est } \\
\text { sig (p) }\end{array}$ \\
\hline True EUGR & $\begin{array}{l}\text { - Weight } \\
\text { Fenton } \\
\text { - Weight IGW- } \\
21 \\
\text { - Length } \\
\text { Fenton } \\
\text { - Length IGW- } \\
21 \\
\text { - HC Fenton } \\
\text { - HC IGW-21 }\end{array}$ & $\begin{array}{l}10(52,6 \%) \\
7(36,8 \%) \\
12(63,2 \%) \\
10(52,6 \%) \\
3(15,8 \%) \\
4(21,1 \%)\end{array}$ & $\begin{array}{l}36(52,9 \%) \\
25(36,8 \%) \\
33(48,5 \%) \\
28(41,2 \%) \\
6(8,8 \%) \\
6(8,8 \%)\end{array}$ & $\begin{array}{l}0,981 \\
0,995 \\
0,259 \\
0,373 \\
0,403^{\star} \\
0,215^{\star}\end{array}$ \\
\hline $\begin{array}{l}\text { Dynamic EUGR } \\
\text { (longitudinal) }\end{array}$ & $\begin{array}{l}\text { - Weight - 1 } \\
\text { DS Fenton } \\
\text { - Weight -1 } 1 \\
\text { DS IGW-21 } \\
\text { - Weight -2 } \\
\text { DS Fenton } \\
\text { - Weight - } 2 \\
\text { DS IGW-21 } \\
\text { - Length - } 1 \\
\text { DS Fenton } \\
\text { - Length - } 1 \\
\text { DS IGW-21 } \\
\text { - Length - } 2 \\
\text { DS Fenton } \\
\text { - Length - } 2 \\
\text { DS IGW-21 } \\
\text { - HC -1 DS } \\
\text { Fenton } \\
\text { - HC -1 DS } \\
\text { IGW-21 } \\
\text { - HC -2 DS } \\
\text { Fenton } \\
\text { - HC -2 DS } \\
\text { IGW-21 }\end{array}$ & $\begin{array}{l}12(63,2 \%) \\
11(57,9 \%) \\
7(36,8 \%) \\
6(31,6 \%) \\
15(78,9 \%) \\
13(68,4 \%) \\
10(52,6 \%) \\
9(47,4 \%) \\
4(21,1 \%) \\
4(21,1 \%) \\
4(21,1 \%) \\
4(21,1 \%)\end{array}$ & $\begin{array}{l}42(61,8 \%) \\
30(44,1 \%) \\
16(23,5 \%) \\
13(19,1 \%) \\
41(60,3 \%) \\
32(47,1 \%) \\
16(23,5 \%) \\
17(25 \%) \\
13(19,1 \%) \\
13(19,1 \%) \\
4(5,9 \%) \\
4(5,9 \%)\end{array}$ & $\begin{array}{l}0,912 \\
0,288 \\
0,245 \\
0,345^{\star} \\
0,133 \\
0,099 \\
0,014 \\
0,060 \\
0,851 \\
0,851 \\
0,065^{\star} \\
0,065^{\star}\end{array}$ \\
\hline OMS at 2 years & $\begin{array}{l}\text { - Weight } \\
\text { OMS <-2DS } \\
\text { - Length } \\
\text { OMS <-2DS } \\
- \text { HC } \\
\text { OMS <-2DS }\end{array}$ & $\begin{array}{l}3(18,8 \%) \\
1(6,3 \%) \\
1(6,3 \%)\end{array}$ & $\begin{array}{l}9(14,3 \%) \\
6(9,5 \%) \\
3(4,8 \%)\end{array}$ & $\begin{array}{l}0,657 \\
0,681 \\
0,808\end{array}$ \\
\hline
\end{tabular}


Table 8

Correlations between the z-scores of the different parameters for gestational age and sex, and the scalar scores of Inhibition, Memory for names, Memory for designs and Route finding, and the IQ for RIST

\begin{tabular}{|c|c|c|c|c|c|}
\hline & RIST & Inhibition & $\begin{array}{l}\text { Memory for } \\
\text { names }\end{array}$ & $\begin{array}{l}\text { Memory for } \\
\text { designs }\end{array}$ & $\begin{array}{l}\text { Route } \\
\text { finding }\end{array}$ \\
\hline $\begin{array}{l}\text { Birth } \\
\text { - Z-score weight Fenton } \\
\text { - Z-score length Fenton } \\
\text { - Z-score HC Fenton } \\
\text { - Z-score weight IGW-21 } \\
\text { - Z-score length IGW-21 } \\
\text { - Z-score HC IGW-21 }\end{array}$ & $\begin{array}{l}0,034 \\
0,001 \\
0,025 \\
0,058 \\
0,002 \\
0,058\end{array}$ & $\begin{array}{l}0,192 \\
0,240 \\
0,019 \\
0,307 \\
0,281 \\
0,035\end{array}$ & $\begin{array}{l}0,514 \\
0,084 \\
0,869 \\
0,675 \\
0,087 \\
0,820\end{array}$ & $\begin{array}{l}0,106 \\
0,255 \\
0,521 \\
0,300 \\
0,378 \\
0,731\end{array}$ & $\begin{array}{l}0,867 \\
0,709 \\
0,280 \\
0,870 \\
0,704 \\
0,390\end{array}$ \\
\hline $\begin{array}{l}\text { At neonatal discharge } \\
\text { - Z-score weight Fenton } \\
\text { - Z-score length Fenton } \\
\text { - Z-score HC Fenton } \\
\text { - Z-score weight IGW-21 } \\
\text { - Z-score length IGW-21 } \\
\text { - Z-score HC IGW-21 }\end{array}$ & $\begin{array}{l}0,004 \\
0,003 \\
0,053 \\
0,003 \\
0,004 \\
0,052\end{array}$ & $\begin{array}{l}0,210 \\
0,324 \\
0,453 \\
0,249 \\
0,221 \\
0,692\end{array}$ & $\begin{array}{l}0,302 \\
0,563 \\
0,942 \\
0,451 \\
0,954 \\
0,976\end{array}$ & $\begin{array}{l}0,609 \\
0,797 \\
0,950 \\
0,680 \\
0,815 \\
0,771\end{array}$ & $\begin{array}{l}0,294 \\
0,433 \\
0,374 \\
0,217 \\
0,393 \\
0,228\end{array}$ \\
\hline $\begin{array}{l}\text { Difference between birth and } \\
\text { neonatal discharge: } \\
\text { - Z-score weight Fenton } \\
\text { - Z-score length Fenton } \\
\text { - Z-score HC Fenton } \\
\text { - Z-score weight IGW-21 } \\
\text { - Z-score length IGW-21 } \\
\text { - Z-score HC IGW-21 }\end{array}$ & $\begin{array}{l}0,733 \\
0,561 \\
0,558 \\
0,579 \\
0,155 \\
0,710\end{array}$ & $\begin{array}{l}0,973 \\
0,765 \\
0,238 \\
0,958 \\
0,772 \\
0,268\end{array}$ & $\begin{array}{l}0,477 \\
0,767 \\
0,507 \\
0,473 \\
0,551 \\
0,707\end{array}$ & $\begin{array}{l}0,109 \\
0,581 \\
0,534 \\
0,365 \\
0,930 \\
0,819\end{array}$ & $\begin{array}{l}0,289 \\
0,232 \\
0,871 \\
0,332 \\
0,169 \\
0,396\end{array}$ \\
\hline $\begin{array}{l}2 \text { years } \\
\text { - Z-score weight OMS } \\
\text { - Z-score height OMS } \\
\text { - Z-score HC OMS }\end{array}$ & $\begin{array}{l}0,736 \\
0,369 \\
0,072\end{array}$ & $\begin{array}{l}0,311 \\
0,037 \\
0,191\end{array}$ & $\begin{array}{l}0,869 \\
0,770 \\
0,989\end{array}$ & $\begin{array}{l}0,936 \\
0,256 \\
0,384\end{array}$ & $\begin{array}{l}0,993 \\
1,000 \\
0,116\end{array}$ \\
\hline
\end{tabular}


Table 9

Differences found in the scalar score (statistically significant) of analyzed tests in the comparison of different somatometric groups, for all cases $(n=87)$.

\begin{tabular}{|c|c|c|c|c|}
\hline & & Yes & No & Est sig \\
\hline Inhibition & $\begin{array}{l}\text { IURG weight Fenton < P10 } \\
\text { IUGR weight IGW-21<P10 } \\
\text { True EUGR weight IGW-21 } \\
\text { Two years height OMS <-2DS } \\
\text { Two years HC OMS <-2DS }\end{array}$ & $\begin{array}{l}9(4) \\
9(4) \\
10(5) \\
6(4) \\
6(4)\end{array}$ & $\begin{array}{l}10(4) \\
10(5) \\
9(5) \\
10(4) \\
10(4)\end{array}$ & $\begin{array}{l}0,034 \\
0,020 \\
0,042 \\
0,038 \\
0,048\end{array}$ \\
\hline Route finding & $\begin{array}{l}\text { Static EUGR HC Fenton <-2DS } \\
\text { Static EUGR HC IGW-21 <-2DS } \\
\text { Dynamic EUGR HC IGW-21 <-2DS }\end{array}$ & $\begin{array}{l}1(2) \\
1 \text { (2) } \\
1(2)\end{array}$ & $\begin{array}{l}2(3) \\
2(3) \\
2(3)\end{array}$ & $\begin{array}{l}0,005 \\
0,020 \\
0,045\end{array}$ \\
\hline RIST & $\begin{array}{l}\text { IUGR weight Fenton } \mathrm{P}<10 \\
\text { IUGR length Fenton < }<10 \\
\text { IUGR length IGW-21<P10 } \\
\text { IUGR HC Fenton < P10 } \\
\text { IUGR HC IGW-21<P10 } \\
\text { Static EUGR length Fenton <-2DS } \\
\text { Static EUGR length IGW-21 <-2DS } \\
\text { Static EUGR HC Fenton < P10 } \\
\text { Static EUGR HC IGW-21 < P10 } \\
\text { Static EUGR HC Fenton <-2DS } \\
\text { Static EUGR HC IGW-21 <-2DS } \\
\text { Two years HC OMS <-2DS }\end{array}$ & $\begin{array}{l}84(20) \\
84(22) \\
84(24) \\
84(18) \\
84(18) \\
84(20) \\
84(19) \\
83(25) \\
85(23) \\
70(12) \\
73(26) \\
70(28)\end{array}$ & $\begin{array}{l}95(25) \\
93(25) \\
93(25) \\
93(25) \\
93(25) \\
93(28) \\
95(28) \\
93(23) \\
92(23) \\
93(22) \\
93(22) \\
92(21)\end{array}$ & $\begin{array}{l}0,037 \\
0,027 \\
0,025 \\
0,006 \\
0,047 \\
0,030 \\
0,010 \\
0,018 \\
0,001 \\
0,043 \\
0,002 \\
0,025\end{array}$ \\
\hline
\end{tabular}

